\title{
PAKAN AMPAS TAHU YANG DIFERMENTASI DENGAN RAGI TAPE UNTUK MENINGKATKAN PERTUMBUHAN DAN KELANGSUNGAN HIDUP BENIH IKAN LELE DUMBO (Clarias Gariepinus)
}

\author{
Maria Yohanista \\ Universitas Nusa Nipa, Maumere, mariayohanista120118@gmail.com
}

\section{https://doi.org/10.31943/gemawiralodra.Vol9.Iss2.353}

\begin{abstract}
ABSTRAK
Pakan merupakan faktor utama yang perlu diperhatikan untuk pertumbuhan Ikan Lele Dumbo (Clarias gariepinus). Proses fermentasi akan menyederhanakan partikel bahan pakan, sehingga akan meningkatkan nilai gizinya. Bahan pakan yang telah mengalami fermentasi akan lebih baik kualitasnya dari bahan bakunya. Fermentasi ampas tahu dengan ragi akan mengubah protein menjadi asam-asam amino, dan secara tidak langsung akan menurunkan kadar serat kasar ampas tahu. Metode yang digunakan adalah Metode Eksperimen. Penelitian menggunakan Rancangan Acak Lengkap (RAL), yaitu terdiri dari 3 perlakuan 3 ulangan yakni perlakuan pemberian pakan ampas tahu yang difermentasi dengan ragi tape $1 \%$, pakan ampas tahu yang difermentasi dengan ragi tape $3 \%$, pakan ampas tahu yang difermentasi dengan ragi tape $5 \%$. Hasil perhitungan dengan menggunakan Rancangan Acak Lengkap dan Analisis Sidik Ragam (ANOVA), diperoleh dari F hitung $<\mathrm{F}$ tabel ${ }_{(0,05)}$ yakni $0,29<5,14$. Ini menunjukan bahwa tidak berbeda nyata atau sama, maka tidak dilanjutkan dengan uji Beda Nyata Terkecil (BNT). Ho diterima, karena hasil penelitian manunjukan bahwa tidak adanya perbedaan penggunaan ampas tahu yang difermentasi menggunakan ragi tape terhadap pertumbuhan dan kelangsungan hidup Ikan Lele Dumbo (Clarias gariepinus). Kelangsungan hidup benih ikan lele dumbo selama penelitian adalah 97,78\% pada semua perlakuan. Kualitas air selama penelitian masih dalam kisaran yang layak untuk pertumbuhan dan kelangsungan hidup benih ikan lele dumbo (Clarias gariepinus).
\end{abstract}

\section{Kata Kunci : ampas tahu, fermentasi, pakan, lele dumbo (Clarias gariepinus)}

\begin{abstract}
Feed is a major factor to note for the growth of Dumbo Catfish (Clarias gariepinus). The fermentation process will simplify the particles of feed ingredients, thus increasing their nutritional value. Feed materials that have been fermented will be better quality than raw materials. Fermentation of tofu waste with yeast will convert the protein into amino acids, and indirectly will decrease the crude fiber content of tofu pulp. The method used is Experiment Method. The research was designed using Completely Randomized Design (RAL), which consisted of 3 treatments 3 replications ie the treatment of feeding dregs of fermented tofu with $1 \%$ yeast tape, the tofu fermented tofu feed was fermented with $3 \%$ tagi yeast, the fermented tofu feed fermented with 5\% yeast tape. The result of calculation by using Completely Random Design and Variable Fingerprint Analysis (ANOVA), obtained from $\mathrm{F}$ arithmetic $<\mathrm{F}$ table $(0,05)$ that is $0,29<5,14$. This shows that it is not significantly different or the same, then it is not followed by the test of the Smallest Real Beda (BNT). $\mathrm{H}_{0}$ accepted, because the results showed that there is no difference in the use of tofu fermented leaf with tape yeast on the growth and survival of Dumbo catfish (Clarias gariepinus). The survival of dumbo catfish seeds during the study was $97.78 \%$ in all treatments. Water quality during the study was within a reasonable range for the growth and survival of dumbo catfish (Clarias gariepinus).
\end{abstract}

Keyword(s): tofu waste, fermentation, dumbo catfish (Clarias gariepinus). 


\section{PENDAHULUAN}

Perikanan adalah suatu kegiatan perekonomian yang memanfaatkan sumber daya alam dengan menggunakan ilmu pengetahuan dan teknologi untuk kesejahteraan manusia dengan mengoptimalisasikan dan memelihara produktivitas sumber daya perikanan serta kelestarian lingkungan. Salah satu komoditas perikanan yang cukup populer di masyarakat adalah lele dumbo (Clarias gariepinus). Ikan ini berasal dari Benua Afrika dan pertama kali didatangkan ke Indonesia pada tahun 1984. Ikan lele dumbo memiliki berbagai kelebihan, diantaranya adalah pertumbuhannya cepat, memiliki kemampuan beradaptasi terhadap lingkungan yang tinggi, rasanya enak dan kandungan gizinya cukup tinggi. Namun dalam kegiatan budidaya ikan lele dumbo mengalami kendala karena harga pakan ikan (pellet), semakin mahal dan kurang terjangkau bagi masyarakat. Oleh karena itu, diperlukan solusi dalam mengatasi masalah ini dengan membuat pakan alternatif yang murah dan berkualitas. Salah satunya dengan memanfaatkan ampas tahu yang difermentasikan dengan ragi tape.

Ampas tahu masih memiliki kandungan nutrisi yang cukup untuk digunakan sebagai pakan ikan lele dumbo antara lain kandungan protein kasar 27,55\%, lemak 4,93\%, dan serat kasar $23,58 \%$ akan tetapi kadungan asam amino yang rendah dan serat kasar yang tinggi menjadi faktor pembatas dalam penggunaannya sebagai pakan. Oleh karena itu, harus ada teknologi pendahulu sebelum diberikan sebagai pakan ikan lele dumbo. Teknologi yang digunakan salah satunya adalah fermentasi.

Fermentasi bekerja dengan bantuan mikroorganisme yang bekerja pada media biakan. Salah satu media biakan yang dapat digunakan adalah ragi tape. Ragi biasanya mengandung mikroorganisme yang melakukan fermentasi dan media biakan bagi mikroorganisme tersebut. Proses fermentasi akan menyederhanakan partikel bahan pakan, sehingga akan meningkatkan nilai gizinya. Bahan pakan yang telah mengalami fermentasi akan lebih baik kualitasnya dari bahan bakunya salah satunya adalah mengubah protein menjadi asam-asam amino, dan secara tidak langsung akan menurunkan kadar serat kasar ampas tahu. Hal ini sejalan dengan hasil penelitian Melati et al.,(2010) menyatakan bahwa Pemanfaatan ampas tahu terfermentasi sebagai substitusi tepung kedelai dalam formulasi pakan ikan yang menggunakan A. niger menunjukkan terjadinya kenaikan protein yang cukup signifikan dari 15,40 menjadi $35,36 \%$ yang diduga kenaikan protein tersebut disebabkan kenaikan jumlah massa Aspergilus niger. Ditambahkan hasil penelitian yang 
telah dilakukan oleh Mulia, et al., (2015) bahwa fermentasi ampas tahu dengan $R$. oligosporus dapat meningkatkan kualitas ampas tahu sebagai bahan baku pakan ikan dimana perlakuan ampas tahu dengan 2,5 mL suspensi Rhizopus oligosporus merupakan perlakuan yang paling baik karena menghasilkan kualitas protein dan kadar abu tinggi, dan menurunkan kadar lemak paling banyak.

Hasil penelitian Melati et al, (2010) menerangkan pengunaan ampas tahu melalui sebagai pakan ikan patin dan menujukan hasil terbaik dari kombinasi ampas tahu $75 \%$ dan tepung tapioka $25 \%$ dapat meningkatkan protein $129,58 \%$, dibanding kombinasi lainnya. Tribina (2012) juga menerangkan pengunaan ampas tahu sebagai pakan ikan nila merah dan menjelaskan pemberian jumlah pakan dari limbah tahu memberi pengaruh pertumbuhan pada ikan nila. Ditambahkan penelitian Rahmi, et al (2014) menerangkan hal yang sama terhadap pertumbuhan ikan mas (Cyprinus carpio L.). Sedangkan hasil penelitian Anggraeni \& Rahmiati (2016) menyatakan bahwa pemberian pakan kadar ampas tahu dapat meningkatkan pertumbuhan ikan lele dimana pemberian pakan terbaik pada perlakuan campuran ampas tahu ditambah kepala udang, menghasilkan nilai bobot pertumbuhan yang paling tinggi.

Dari latar belakang diatas penulis tertarik mengambil penelitian dengan judul Penggunaan Pakan Ampas Tahu yang Difermentasi dengan Ragi Tape Untuk meningkatkan Pertumbuhan dan Kelangsungan Hidup Benih Ikan Lele Dumbo (Clarias agriepinus). Tujuan penelitian ini untuk mengetahui dosis mana yang paling tepat dalam pemberian pakan yang berfermentasi terhadap pertumbuhan dan kelangsungan hidup benih ikan lele dumbo (Clarias gariepinus).

\section{METODE PENELITIAN}

Penelitian ini menggunakan metode eksperimen dan Rancangan Acak Lengkap (RAL), dengan 3 perlakuan dan 3 kali ulangan. Perlakuan meliputi $\mathrm{A}=$ Pakan berfermentasi + dosis ragi tape $1 \%, \mathrm{~B}=$ Pakan berfermentasi + dosis ragi tape 3 $\%$ dan $\mathrm{C}=$ Pakan berfermentasi + dosis ragi tape $5 \%$.

\section{Prosedur Penelitian}

\section{Tahap Persiapan}

a. Persiapan wadah atau media hidup ikan Lele Dumbo (Clarias gariepinus)

b. Persiapan alat dan bahan untuk fermentasi ampas tahu

c. Proses fermentasi. 
Tahap Penimbangan dan Pemberian Pakan

a. Penimbangan agar disesuaikan dengan berat ikan yaitu $3-5 \%$ dari total bobot ikan yang dipelihara

b. Pemberian pakan secara adlibitum (selalu tersedia) dengan rekuensi pemberian pakan yaitu pagi hari (09.00), siang hari (17.00) dan sore hari (20.00).

Variabel pengamatan

Variabel yang diamati dalam penelitian ini adalah:

1. Pertumbuhan berat mutlak

2. Kelangsungan hidup (Survival rate)

3. Kualitas air (Suhu, Derajat keasaman/pH), Salinitas)

\section{Analisa Data}

\section{Pertumbuhan Mutlak}

Menggunakan Rumus

$$
\Delta \mathrm{W}=\mathrm{Wt}-\mathrm{Wo}
$$

Di mana :

$\Delta \mathrm{W}=$ Pertumbuhan Mutlak

$\mathrm{Wt}=$ Berat Ikan Lele Dumbo pada ahkir penelitian (gr)

Wo $=$ Berat Ikan Lele Dumbo pada awal penelitian (gr)

2. Konversi Pakan (FCR)

Dihitung dengan Rumus sebagai berikut :

$\mathrm{FCR}=\frac{\text { Makanan yang dimakan }(\mathrm{gr})}{\text { Pertambahan Berat }(\mathrm{gr})}$

3. Survival Rate

Rumus untuk mencari Survival Rate

$$
\mathrm{SR}=\frac{\mathrm{Nt}}{\mathrm{No}} \times 100 \%
$$

Dimana :

SR : Survival Rate

$\mathrm{Nt}$ : Jumlah lele dumbo hidup pada akhir Penelitian

No : Jumlah lele dumbo pada awal penelitian

Data yang diperoleh dari penelitian ini dianalisis dengan uji Analysis of Variance (ANOVA) dan uji DMRT (Duncan Multiple Range Test) dengan taraf uji 5\%. 


\section{HASIL DAN PEMBAHASAN}

Berdasarkan pengamatan dan sampling yang dilakukan selama pemeliharaan 6 minggu, ikan lele dumbo mengalami pertumbuhan bobot dari 6,8-6,8 gram menjadi 13,90 - 14,27 gram. Pemberian ampas tahu yang terfermentasi mampu meningkatkan pertumbuhan bobot ikan lele dumbo seperti yang dapat terlihat pada Gambar I. Pada setiap sampling yang dilakukan menunjukkan, pertumbuhan bobot tertinggi diperoleh pada perlakuan A kemudian diikuti perlakuan C, dan B.

Hal ini sangat berhubungan erat dengan pakan yang diberikan artinya ampas tahu yang terfermentasi nilai nutrisi semakin meningkat sehingga diserap tubuh dan meningkatkan pertumbuhan. Salah satu nutrisi yang dapat meningkat dalam proses ferementasi adalah protein dimana pada penelitian ini protein ampas tahu meningkat dimana protein memegang peranan penting dalam struktur dan fungsi tubuh, seperti pertumbuhan dan reproduksi. Protein dimanfaatkan oleh ikan untuk fungsi pertumbuhan (anabolisme), namun juga digunakan dalam fungsi katabolik (antara lain bergerak) (Murtidjo ,2001; Rahardjo dkk., 2011; Bulfrit et al, 2017).

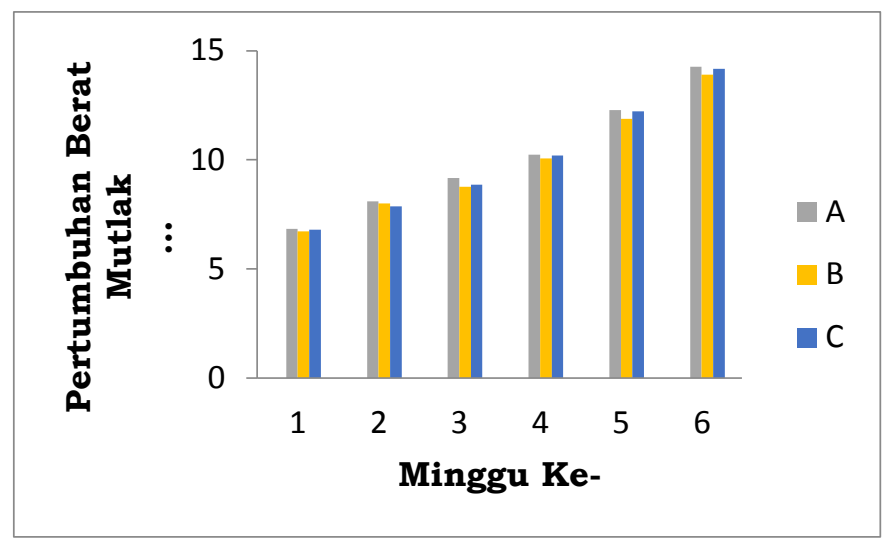

Gambar I. Pertumbuhan Berat Mutlak (gram) Lele Dumbo (Clarias gariepinus)

Pertumbuhan berat rata-rata mutlak ikan lele dumbo yang dipelihara selama 6 minggu menunjukkan bahwa perlakuan terbaik adalah perlakuan A yaitu menggunakan ampas tahu terfermentasi sebesar $1 \%$ dengan pertambahan berat 10,15 gram dan terkecil pada perlakuan B dengan pertambahan berat 9,89 gram yaitu pakan dengan menggunakan ampas tahu terfermentasi $3 \%$. Pertumbuhan barta rata-rata ikan lele dumbo dapat dilihat pada Gambar 2. 


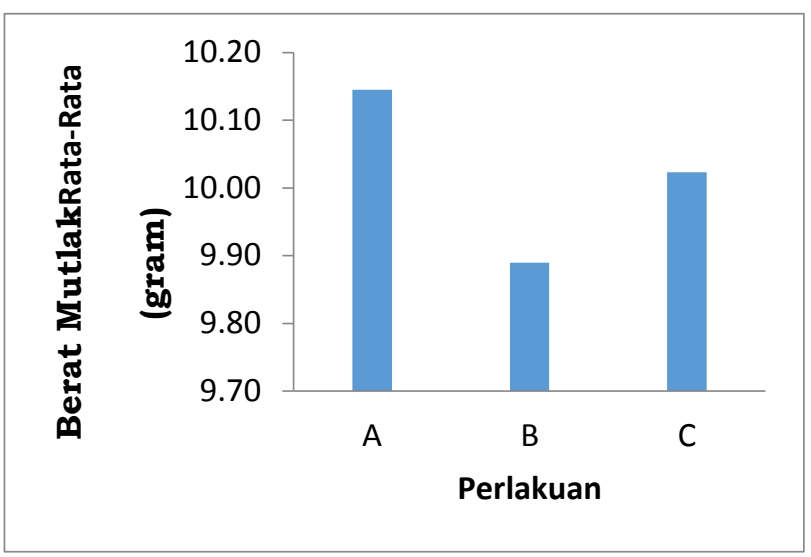

Gambar 2. Berat Mutlak Rata-Rata (gram) Lele Dumbo (Clarias gariepinus)

Dari hasil Analysis of Varians (ANOVA) menunjukkan bahwa perlakuan yang diberikan tidak memberikan pengaruh nyata terhadap pertumbuhan berat mutlak sehigga tidak dilanjutkan dengan uji lanjut Beda Nyata Jujur (BNJ).

Menurut Effendie (2000); Prihadi (2007); Bulfrit et al. (2017), Pertumbuhan adalah pertambahan ukuran panjang atau berat dalam satuan waktu yang dipengaruhi oleh beberapa faktor, seperti keturunan, umur, parasit, pakan dan kondisi perairan. Pertumbuhan ikan lele dumbo terjadi karena adanya pasokan energi yang terkandung dalam pakan. Energi dalam pakan yang dikonsumsi melebihi kebutuhan energi yang dibutuhkan untuk pemeliharaan tubuh dan aktifitas tubuh lainnya, sehingga kelebihan energi tersebut dimanfaatkan ikan untuk pertumbuhan.

\section{Pertumbuhan Panjang Mutlak}

Berdasarkan pengamatan dan sampling yang dilakukan selama pemeliharaan 6 minggu, ikan lele dumbo mengalami pertumbuhan panjang dari 5,4 - 5,7 cm menjadi 9,2 $10 \mathrm{~cm}$. Pemberian ampas tahu yang terfermentasi mampu meningkatkan pertumbuhan bobot ikan lele dumbo seperti yang dapat dilihat pada Gambar 3. Pada setiap sampling yang dilakukan menunjukkan, pertumbuhan panjang tertinggi diperoleh pada perlakuan $\mathrm{A}$ kemudian diikuti perlakuan $\mathrm{C}$, dan B. 


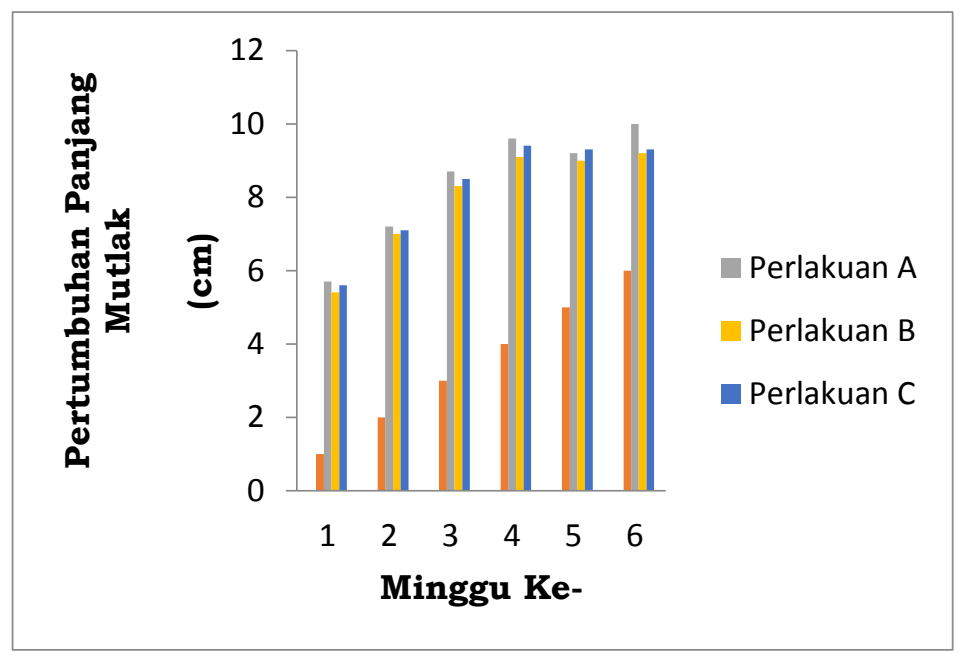

Gambar 3. Pertumbuhan Panjang Mutlak (cm) Lele Dumbo (Clarias gariepinus)

Hal ini menunjukkan bahwa setiap perlakuan dengan pemberian ampas tahu yang terfermentasi tingkat pertumbuhannya tidak berbeda atau sama dimana beberapa faktor yang dapat berpengaruh terhadap pertumbuhan ini diantaranya adalah faktor dari dalam tubuh ikan itu sendiri seperti faktor genetik, serta faktor dari luar/lingkungan seperti pakan. Hal ini seJalan dengan pendapat Sumpeno (2010) bahwa pertumbuhan ikan dipengaruhi oleh dua faktor, yaitu faktor internal yang meliputi sifat genetik dan kondisi fisiologis ikan serta faktor eksternal yang berhubungan dengan pakan dan lingkungan.

Pertumbuhan panjang rata-rata mutlak ikan lele dumbo yang dipelihara selama 6 minggu menunjukkan bahwa perlakuan terbaik adalah perlakuan A yaitu menggunakan ampas tahu terfermentasi sebesar $1 \%$ dengan pertambahan berat $8,40 \mathrm{~cm}$ dan terkecil pada perlakuan $\mathrm{B}$ dengan pertambahan berat $8,0 \mathrm{~cm}$ yaitu pakan dengan menggunakan ampas tahu terfermentasi $3 \%$. Pertumbuhan barta rata-rata ikan lele dumbo dapat dilihat pada Gambar 4.

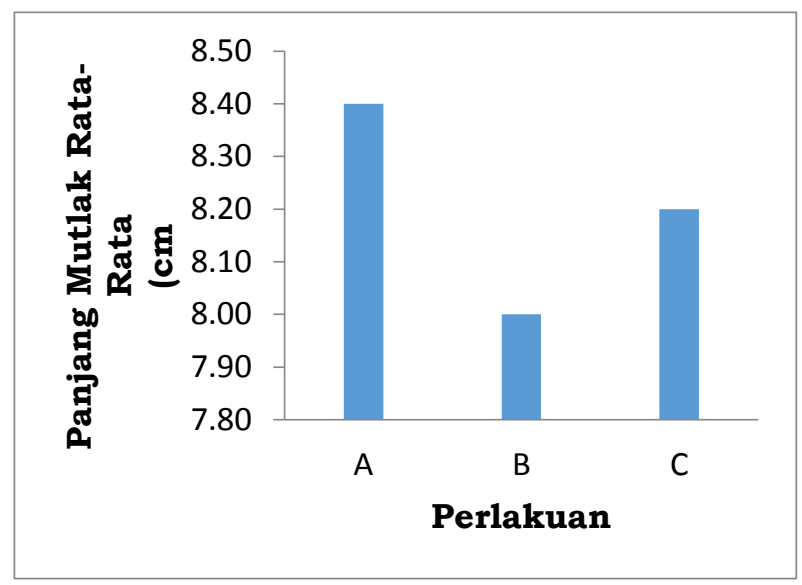


Gambar 4. Panjang Mutlak Rata-Rata (gram) Lele Dumbo (Clarias gariepinus)

Hasil perhitungan dengan menggunakan Rancangan Acak Lengkap (RAL) dan Analisis Ragam (ANOVA) diperoleh dari $\mathrm{F}$ hitung $<\mathrm{F} \operatorname{tabel}_{(0,05)}$ yakni $0,29<5,14$. Ini menunjukan bahwa tidak berbeda nyata, maka tidak dilanjutkan dengan uji Beda Nyata Terkecil (BNT) sehingga dari penelitian ini dapat disimpulkan bahwa hasil $\mathrm{H}_{0}$ diterima $\mathrm{H}_{1}$ ditolak karena hasil penelitian manunjukan bahwa Pemberian Pakan ampas tahu yang difermentasi dengan ragi tape 1\%, 3\% dan 5\% tidak berbeda nyata atau sama terhadap pertmbuhan panjang mutlak ikan lele selama penelitian.

\section{Konversi Pakan}

Konversi pakan (FCR) merupakan perhitungan untuk mencari nilai persentase koefisien pakan yang diberikan berdasarkan perbandingan antara besarnya pertambahan berat terhadap jumlah pakan yang diberikan pada benih ikan Lele dumbo. Nilai FCR akan berbanding terbalik dengan nilai efisiensi pakan artinya jika semakin rendah nilai FCR makan nilai efisiensi pakan akan semakin tinggi ataupun sebaliknya. Hal ini juga sesuai dengan pendapat Marlitha (2013) semakin besar nilai efisiensi pemberian pakan, maka semakin baik ikan memanfaatkan pakan yang diberikan sehingga semakin besar bobot daging yang dihasilkan.

Perhitungan konversi pakan selama penelitian adalah berkisar antara 2,84 sampai 2,88, artinya untuk membentuk 1 gram berat ikan pakan yang diperlukan adalah 2,44 gram sampai 2,88 gram. Nilai FCR selama penelitian yang terrendah adalah perlakuan A yaitu 2,81\%; Perlakuan C yaitu 2,84\% dan Perlakuan B yaitu 2,88 \%, dapat di lihat pada Gambar 5.

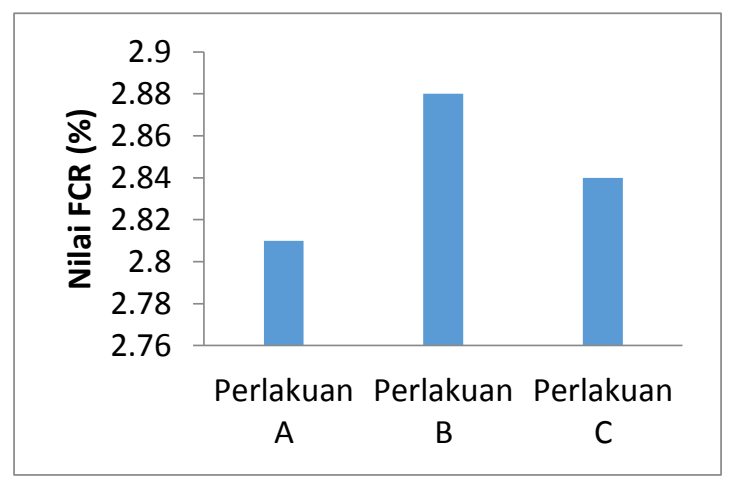

Gambar 5. Nilai FCR (\%) Lele Dumbo (Clarias gariepinus) 
Tingginya nilai FCR pakan selama penelitian diduga dipengaruhi oleh komposisi nutrisi pakan uji penelitian tidak seimbang dan tidak sesuai dengan kebutuhan nutrisi ikan lele dumbo sehingga pertumbuhan ikan lele dumbo selama peelitian menjadi lambat. Hal ini sebanding dengan pendapat Gusrina (2008); makin sedikit pakan yang diberikan, maka nilai FCR semakin kecil sehingga semakin efisien dan berkualitas tinggi pakan yang digunakan (Gusrina, 2008). Ditambahkan Lumenta (2006); Bulfrit et al. (2017) bahwa nilai konversi pakan yang baik berkisar antara $\leq 2$.

Hasil perhitungan dengan menggunakan Rancangan Acak Lengkap (RAL) dan Analisis Ragam (ANOVA) diperoleh dari $\mathrm{F}$ hitung $<\mathrm{F}$ tabel $_{(0,05)}$ artina bahwa tidak berbeda nyata, maka tidak dilanjutkan dengan uji Beda Nyata Terkecil (BNT) sehingga dari penelitian ini dapat disimpulkan bahwa hasil $\mathrm{H}_{0}$ diterima $\mathrm{H}_{1}$ ditolak karena hasil penelitian manunjukan bahwa pemberian pakan ampas tahu yang difermentasi dengan ragi tape $1 \%, 3 \%$ dan $5 \%$ tidak berbeda nyata atau sama pada variabel ukur nilai FCR ikan lele dumbo.

Dimana perbedaan nilai FCR dipengaruhi oleh spesies, ukuran dan umur ikan, kebiasaan makan, ukuran, kualitas air dan pakan yang diberikan. Kesukaan organisme terhadap makanan dipengaruhi oleh penyebaran organisme, ketersedian bahan pakan, faktor pilihan ikan dan faktor fisik yang mempengaruhi perairan. Nilai konversi pakan sebenarnya bukan merupakan angka mutlak, karena tidak hanya ditentukan oleh kualitas pakan, akan tetapi dipengaruhi pula oleh faktor-faktor lain seperti jenis ikan dan ukuran ikan, jumlah padat tebar, kualitas air, dan faktor genetik (Akbar., et al, 2010; Fran\&Junius,2015).

\section{Kelangsungan Hidup}

Salah satu tolak ukur untuk mengetahui bahwa keberhasilan dalam budidaya lele dumbo adalah tingkat atau presentase kelangsungan hidup dimana akan di ketahui juga tingkat mortalitas selama pemeliharaan. Kelangsungan hidup dipengaruhi oleh kualitas air media pemeliharaan dan pakan yang diberikan. 


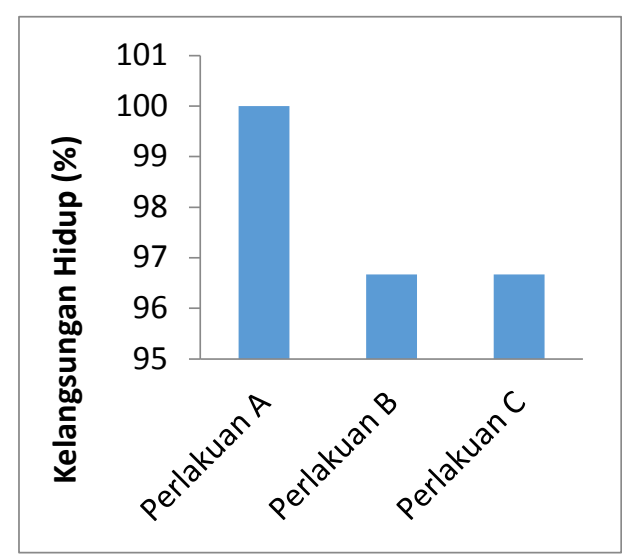

Gambar 6. Kelangsungan Hidup (\%) Lele Dumbo (Clarias gariepinus)

Pada Gambar 6, terlihat bahwa tingkat kelangsungan hidup tertinggi pada perlakuan A (100\%), sedangkan pada perlakuan B dan C $(96,67 \%)$. Hal ini menunjukkan bahwa ikan lele dumbo dapat beradaptasi dengan lingkungan dan pakan uji yang di berikan. Selain itu kualitas air selama penelitian masih dalam keadaan yang layak untuk menunjang derajat kelangsungan hidup benih ikan lele dumbo (Clarias gariepinus).

Hasil perhitungan dengan menggunakan Rancangan Acak Lengkap (RAL) dan Analisis Ragam (ANOVA) diperoleh dari $\mathrm{F}$ hitung $<\mathrm{F}$ tabel $_{(0,05)}$ yakni 0,00045 < 5,14. Ini menunjukan bahwa tidak berbeda nyata, maka tidak dilanjutkan dengan uji Beda Nyata Terkecil (BNT) sehingga dari penelitian ini dapat disimpulkan bahwa hasil $\mathrm{H}_{0}$ diterima $\mathrm{H}_{1}$ ditolak karena hasil penelitian manunjukan bahwa Pemberian Pakan ampas tahu yang difermentasi dengan ragi tape $1 \%, 3 \%$ dan $5 \%$ tidak berbeda nyata atau sama pada variable ukur kelangsungan hidup ikan lele dumbo. Namun pada perlakuan A kelangsungan hidup sebesar $100 \%$, sedangkan nilai kelangsungan hidup terendah dari setiap perlakuan diperoleh pada perlakuan B dan perlakuan C yaitu 96,67\%.

\section{Kualitas Air}

Suhu

Hasil pengukuran suhu selama penelitian adalah $23-31{ }^{0} \mathrm{C}$. Suhu tersebut masih sesuai dengan lingkungan hidupnya, dimana pertumbuhan lele terhambat pada suhu kurang dari $20^{\circ} \mathrm{C}$ (Suyanto, 2007; Mufidah et al., 2009). Suhu air yang sesuai akan meningkatkan aktivitas makan ikan, sehingga menjadikan ikan lele dumbo cepat tumbuh sedangkan jika suhu pemeliharaan kurang dari kisaran (suhu rendah), mengakibatkan aktivitas lele dumbo 
menjadi rendah dan nafsu makan berkurang, sehingga akan mengakibatkan pertumbuhan lele dumbo menjadi lambat.

\section{Derajat keasaman (pH)}

Kemampuan air untuk mengikat atau melepaskan sejumlah ion hidrogen akan menunjukkan apakah larutan tersebut bersifat asam atau basa. Nilai $\mathrm{pH}$ yang terukur selama penelitian berkisar 6 - 7, merupakan $\mathrm{pH}$ yang optimal. $\mathrm{pH}$ tersebut sesuai untuk pemeliharaan lele berkisar antara 6,5-8 (Gunder and Fink, 2008; Mufidah et al., 2009).

\section{Salinitas}

Pengukuran salinitas air selama penelitian dengan menggunakan Refaktometer pada ketiga perlakuan (9 ember), hasilnya sama yaitu salinitasnya 0,3 ppt.

\section{KESIMPULAN}

Berdasarkan hasil penelitian yang telah dilaksanakan maka disimpulkan bahwa pemberian pakan ampas tahu yang difermentasi dengan dosis ragi tape yang berbeda (1\%, $3 \%$ dan $5 \%$ ) tidak berpengaruh terhadap pertumbuhan bobot dan kelangsungan hidup benih ikan lele dumbo (Clarias gariepinus).

\section{UCAPAN TERIMAKASIH}

LPPM Universitas Nusa Nipa Maumere yang telah memberikan bantuan dana serta kesempatan dalam pelaksanaan penelitian ini.

\section{DAFTAR PUSTAKA}

Anggraeni D \& Rahmiati. (2016). Pemanfaatan Ampas Tahu Sebagai Pakan Ikan Lele (Clarias batrachus) Organik. Jurnal Ilmiah Biologi (BIOGENESIS), 4(1), 53 - 57

Bulfrit B. R., Cyska L \& Jeffrie F.M. (2017). Pemanfaatan ragi (Saccharomyces cerevisiae) pada formulasi pakan dalam meningkatkan pertumbuhan ikan Nila (Oreochromis niloticus). Jurnal Budidaya Perairan, 5(3), 44 - 49

Dini S.M.D., Eka Y., Heri M \& Cahyono P. (2015). Peningkatan Kualitas Ampas Tahu Sebagai Bahan Baku Pakan Ikan Dengan Fermentasi Rhizopus oligosporus. Sainteks, 12(1), $10-20$

Fran S \& Junius A. (2015). Pengaruh Perbedaan Tingkat Protein Dan Rasio Protein Pakan Terhadap Pertumbuhan Ikan Sepat (Trichogaster pectoralis). Fish Scientiae, 3(5), 53-63

Gunder, H \& W. Fink. (2008). Clarias gariepinus. North African Catfish. Museum of Zoology. Animal Diversity Web. University of 
Michigan.http://animaldiversity.ummz.umich.edu/site/accounts/information/Clarias gariepinus.html.

Heriansah \& Dian N. (2016). Pembuatan Pakan dengan Bahan Baku Lokal, Penggunaan Probiotik dan Penerapan Manajemen Usaha Bagi Kelompok Pembudidaya Ikan di Kecamatan Citta Kabupaten Soppeng. Jurnal Balik Diwa. 7(2), 30 - 37.

Hidayat \& Muhammad K. (2010). Pemanfaatan Ampas Tahu Sebagai Bahan Dasar Alternatif Pakan Buatan Untuk Ikan Lele. Tesis Universitas Muhammadiyah Malang

Mahyudin, Kholis. (2008). Panduan Lengkap Agribisnis Lele. Jakarta: Penebar Swadaya.

Marlitha, M. (2013). Pemanfaatan Limbah Roti Dalam Pakan Buatan Terhadap Pertumbuhan dan Efisiensi Pakan Benih Lele Dumbo (Clarias gariepinus). Tesis. Universitas Padjadjaran.

Melati I., Zafril I.A \& Titik. (2010). Pemanfaatan Ampas Tahu Terfermentasi Sebagai Substitusi Tepung Kedelai Dalam Formulasi Pakan Ikan Patin. Forum Inovasi Teknologi Akuakultur (hal 713 - 719). Bogor: Balai Riset Perikanan Budidaya Air Tawar.

Mulia, D.S., Eka Y., Heri M., \& Cahyono, P. (2015). Peningkatan Kualitas Ampas Tahu Sebagai Bahan Baku Pakan Ikan Dengan Fermentasi Rhizopus oligosporus. Jurnal Sainteks, 12 (1), 10 - 20

Mufidah, N.B.W., Boedi S.R \& Woro H.S. (2009). Pengkayaan Daphnia spp. dengan Viterna Terhadap Kelangsungan Hidup dan Pertumbuhan Larva Ikan Lele Dumbo (Clarias gariepinus). Jurnal Ilmiah Perikanan dan Kelautan, 1(1), 59 - 65

Rahmi E, Nurhadi dan Abizar. (2014). Pengaruh Pakan dari Ampas Tahu yang Difermentasi dengan Em4 Terhadap Pertumbuhan Ikan Mas (Cyprinus carpio L.). Tesis. STKIP PGRI Sumatera Barat.

Tribina, A. (2012). Pemanfaatan Silase Kering Ampas Tahu Untuk Pakan Ikan Nila Merah (Oreochromis nilaticus). Jurnal Teknologi Perikanan dan Kelautan. 2(1), 27 - 33

Winarno, F.G \& S. Fardiaz. (1979). Biofermentasi dan Biosintessa Protein. Bandung: Angkasa.

Winarno, F.G. (2008). Kimia Pangan dan Gizi. Edisi Terbaru. Jakarta: Gram 